\title{
EFFECT OF BENEFICIAL MICROORGANISMS ON COWPEA PRODUCTIVITY AND SOIL HEALTH
}

\author{
A. K. Sarma ${ }^{1}$ and P. N. Bhattacharyya ${ }^{2}$ \\ ${ }^{I}$ Division of Natural Resource Management, ICAR Research Complex for NEH Region, Umiam 793103, Meghalaya, \\ India \\ ${ }^{2}$ Mycology and Microbiology Department, Tocklai Tea Research Institute, Tea Research Association, Jorhat 785008,
} Assam, India

*Corresponding Author: -

E-mail:anjan_icar@rediffmail.com

\begin{abstract}
: -
Soil microorganisms are the most abundant biota in soil, responsible for a number of abilities such as nutrient cycling and organic matter decomposition, maintenance of soil fertility and restoration and plant health and sustainability in ecosystem functioning. Beneficial microbial inoculants such as actinomycetes, diazotrophic bacteria, mycorrhizal helper bacteria (MHB), mycorrhizal fungi, rhizobia etc. are known to promote plant growth. Microorganisms are also antagonistic to plant pests, parasites or diseases. Many of the beneficial microbials are naturally present in soil, although in certain cases, it may be advised to increase their populations and activity either through direct inoculation or by applying agricultural management techniques. In cognizance with the above, an experiment was conducted to evaluate the effect of microbial inoculants on overall productivity of cowpea and soil health. Results revealed that the application of Rhizobium sp. as seed treatment increased the productivity of cowpea (up to 15\%) at various stages of plant growth parameters like plant dry weight, no. of fresh leaves and branches, pods, overall leaf moisture and root length as compared to control. Total microbial population numbers, available $K$ and phosphorus $(P)$ in soil were also increased significantly after the soil was treated with this microbial inoculant indicating the role of beneficial microbial in improving the plant nutrient status and soil health.
\end{abstract}

Keywords: - Cowpea. Microbial inoculants. Mycorrhizal helper bacteria. Plant nutrient status. Rhizobium sp.

\section{(a) $(\$)$}




\section{INTRODUCTION}

Soil is as an excellent medium for the normal growth and development of plants as well as microbes (Tilak et al. 2005; Bouizgarne 2013; Sharma et al. 2015). The plant-microbe interaction in soil is either beneficial or harmful. The beneficial plant-microbe interactions are caused by symbiotic or nonsymbiotic bacteria and a highly specialized group of fungi (mycorrhizal fungi). Enhancement in nutrient acquisition pathway, production of plant growth regulators, alterations in physiological and biochemical properties of the host plant and defending the plant roots against soil-borne pathogens are the possible mechanisms usually involved during this beneficial association (Bhattacharyya and Jha 2012). Beneficial microorganisms are known to stimulate the plant growth and enhance their resistance to plant pathogens as well against abiotic stresses. According to Sinha et al. (2014), beneficial microorganisms can keep the soil environment rich in all kinds of micro and macro nutrients via nitrogen fixation, phosphate and potassium solubilisation or mineralization, release of plant growth regulating substances, production of antibiotics and biodegradation of organic matter in the soil. Bacterial genera such as Azospirillum, Bacillus, Pseudomonas, Rhizobium, Serratia, Stenotrophomonas and Streptomyces fall under this category. These are known as plant growth promoting rhizobacteria (PGPR). Growth promoting substances are produced in large quantities by these soil microorganisms that influence indirectly on the overall morphology of the plants. Mycorrhizal fungi, on the other hand are known for its symbiotic associations with the roots of many different plants ranging from garden vegetables up to the trees of old growth forests. Approximately 6000 species of Glomeromycotina, Ascomycotina and Basidiomycotina are reported as mycorrhizal (Bonfante 2009). There exits mycorrhizal helper bacteria (MHB) that usually get involved in this mycorrhizal establishment and functioning.

Plant nutrition is essential for optimum crop yield and quality maintenance. The availability of required nutrients, together with the degree of interaction between the nutrients and the soil, play a vital role in crop development. A deficiency in any one of the required nutrient can limit plant growth. Beneficial microbes when applied as seed or soil inoculants, they generally multiply and participate in nutrient cycling and thereby benefit crop productivity (Singh et al. 2011). In general, $60-90 \%$ of the total applied fertilizer is lost and the remaining 10-40\% is taken up by the plants. In this regard, microbial inoculants have paramount significance in integrated nutrient management (INM) to sustain agricultural productivity and thereby to adopt a cost-effective and eco-friendly environment (Adesemoye et al. 2009a). Plant growth promoting rhizobacteria (PGPR) or co-inoculants of PGPR and arbuscular mycorrhizal fungi (AMF) can advance the nutrient use efficiency of plants. A synergistic interaction of PGPR and AMF has better suited to $70 \%$ fertilizer plus AMF and PGPR for P uptake. Similar trend were also reflected in N uptake on a whole-tissue basis, where, $75 \%, 80 \%$, or $90 \%$ fertilizer plus inoculants were significantly comparable to $100 \%$ fertilizer application (Adesemoye et al. 2009b). Application of plant growth promoting rhizobacteria (PGPRs), ecto and endo mycorrhizal fungi, cyanobacteria, plant disease suppressive beneficial bacteria, stress tolerance endophytes and bio-degrading microbes (Singh et al. 2011) and many other useful microorganisms led to advancement in soil physico-chemical properties, improved nutrient uptake, plant growth and tolerance to abiotic and biotic stress (Bharadwaj et al. 2014).

Pulses are important because of their nutritional security, crop diversification and sustainable crop production system; pulses are also the cheapest source of proteins for vegetarians. Cowpea (Vigna unguiculata L.) is one of the important annual food crop grown mainly to be used as pulse, vegetable and fodder (Ushamalini et al. 1998). It is usually consumed as food in the form of dried seed. Cowpea is drought-tolerant warm-weather crop well adapted to the drier regions of the tropics, where other food legumes do not perform well. It has ability to fix atmospheric nitrogen through root nodules. Poor soil with more than $85 \%$ sand, less than $0.2 \%$ organic matter and low level of phosphorus is favourable for the growth of cowpea (Singh 2003). Rhizobium has been used as an efficient nitrogen fixer for many years. It plays an important role in increasing crop yield by converting atmospheric nitrogen into usable forms (Sharma et al. 2011). Being resistant to different temperature ranges, Rhizobium enters the root hairs, multiplies and form nodules (Nehra et al. 2007). Rhizobium inoculants are reported to increase the grain yields of bengal gram (Patil et al. 1974), lentil (Rashid et al. 2012), pea, alfalfa and sugar beet (Ramachandran et al. 2011), berseem (Hussain et al. 2002), ground nut (Sharma et al. 2011) and soybean (Grossman et al. 2011). Khaitov et al. (2016) reported an inoculation effect of chickpea with Rhizobium strains that significantly increased shoot, root dry matter, nodule number, shoot length, root length, shoot dry weight, root dry weight, pod number and yield by $17,12,52,43,36,64,28,55 \%$ respectively over control (uninoculated). Significant improvement in soil nutrient status such as total nitrogen, available phosphorus and organic carbon content after microbial inoculation was also observed. In cognizance with the above, a field experiment was conducted in the present investigation to evaluate the effect of beneficial microbial inoculants like Rhizobium sp. on overall productivity of cowpea and soil health.

\section{Materials and methods}

Field experiments were conducted under terrace land situation of Meghalaya, India. The soil of the experimental field was acidic ( $\mathrm{pH}$ : 4.7) containing $2.1 \%$ organic carbon, $259,13.8$ and $112 \mathrm{~kg} \mathrm{ha}^{-1}$ of $\mathrm{N}, \mathrm{P}_{2} \mathrm{O}_{5}$ and $\mathrm{K}_{2} \mathrm{O}$ respectively. The initial fungal and bacterial population in the soil was $16 \times 10^{5} \mathrm{~g}^{-1}$ and $149 \times 10^{6} \mathrm{~g}^{-1}$ soil respectively. Treatments comprised of recommended doses of fertilizer (RDF) i.e. 20-6040 kg ha-1 of $\mathrm{N}, \mathrm{P}_{2} \mathrm{O}_{5}$ and $\mathrm{K}_{2} \mathrm{O}$ and $\mathrm{RDF}+$ Rhizobium sp. Fertilizers as per the treatment were applied in the form of urea, single super phosphate (SSP) and muriate of potash (MOP). Cowpea was sown in rows $30 \mathrm{~cm}$ apart. Thinning operation was done after germination to maintain inter row spacing of $8 \mathrm{~cm}$ between the plants. Rhizobium sp. was applied as seed treatment @ $10 \mathrm{ml} / \mathrm{kg}$ of seed. The crop was sown in the month of April and harvested on June in both the years. The yield and yield attributes were recorded after the harvest.

Soil samples were collected after harvest of the crop from the experimental plot $(0-30 \mathrm{~cm}$ depth) and air dried in the laboratory. Further the samples were sieved through $2 \mathrm{~mm}$ sieve, and analyzed for various parameters such as $\mathrm{pH}$, available N, P, and K. Soil pH (1:2.5 soil/water) was measured using a glass electrode. Available N was estimated using the alkaline 
$\mathrm{KMnO}_{4}$ distillation method (Subbiah and Asija 1956), available P by the Bray-I method (Bray and Kurtz, 1945), and available K by ammonium acetate extraction followed by emission spectrometry (Jackson 1962).

Bacterial and fungal population in soils $(0-30 \mathrm{~cm}$ depth) were determined by serial dilution technique on nutrient agar media and rose bengal agar media respectively. In this technique, a soil suspension was prepared by adding $1.0 \mathrm{~g}$ soil to $10 \mathrm{ml}$ sterile distilled water (SDW) and vortexed. Each suspension was serially diluted starting from $10^{-1}$ to $10^{-6}$. Briefly, $0.1 \mathrm{ml}$ of $10^{-6}$ (for bacteria) and $10^{-5}$ (for fungi) dilution was pipette onto the petriplate containing nutrient agar media and rose bengal agar media respectively and spread with a glass spreader and incubated at $28{ }^{\circ} \mathrm{C}$ for fungal and $35{ }^{\circ} \mathrm{C}$ for bacterial observation. Each colony that appeared on the plate after incubation was considered as one colony forming unit (cfu) (Waksman 1927; Nazir 2007). The number of cfu formed in the petriplate was multiplied by reciprocal of dilution factor to determine the number of population/gram soil.

\section{Result and discussion}

Application of Rhizobium sp. in combination with recommended dose of fertilizer significantly influenced the yield attributing components and yield of cowpea. Pod length, pod weight and pod yield were found significantly higher in the treatment RDF + Rhizobium sp. compared to recommended dose of fertilizer alone (Fig. 1, Fig. 2 and Fig. 3). Combined application of recommended doses of fertilizer along with Rhizobium sp. resulted in higher build-up of $\mathrm{N}_{2} \mathrm{P}_{2} \mathrm{O}_{5}$, and $\mathrm{K}_{2} \mathrm{O}$ in the post-harvest soil as compared to recommended dose of fertilizer alone (Fig 4, Fig. 5, Fig. 6).

Soil microbial population (both bacteria and fungi) in post-harvest soil was also found significantly higher in the treatment having RDF + Rhizobium sp. as compared to RDF (Fig. 7, Fig. 8). The increase in crop yield and other yield attributes might be due to Rhizobium sp. Positive effect of Rhizobium sp. on yield of Phaseolus vulgaris was reported by Rad et al. (2014). During the experiment, longest pod and the maximum seed/plant and the maximum seed yield were obtained from treatment of seed inoculation with Rhizobium leguminosarum.

Similarly, the positive effect of Rhizobium sp. on crop growth and yield was also reported by Mfilinge et al. (2014) and Tagore et al. (2013). Application of Rhizobium sp. along with recommended doses of fertilizer exerted significant influence on build up available $\mathrm{N}, \mathrm{P}_{2} \mathrm{O}_{5}$ and $\mathrm{K}_{2} \mathrm{O}$. This result was in accordance of result of Fatima et al. (2007). They reported that, soybean seed inoculated with Rhizobium sp. increased the yield and improved soil fertility for sustainable agriculture system. Improvement in soil bacterial and fungal population in the treatment having Rhizobium along with RDF might be due to adequate supply of nutrient and energy from applied Rhizobium sp. Increase in the microbial population numbers in soil after treating the soil with Rhizobium sp. was also reported by Trabelsi and Mhamdi (2013).

\section{Conclusion}

Hence, it can be concluded that application of beneficial microorganism like Rhizobium sp. as seed treatment along with recommended doses of fertilizer is beneficial for realizing the higher productivity of cowpea and improvement in soil health.

\section{References}

[1].Adesemoye AO, Kloepper JW 2009a. Plant-microbes interactions in enhanced fertilizer use efficiency. Appl Microbiol Biotechnol, 85: 1-12. doi: 10.1007/s00253-009-2196-0.

[2].Adesemoye AO, Torbert HA, Kloepper JW 2009b. Plant growth-promoting rhizobacteria allow reduced application rates of chemical fertilizers. Micro Ecol, 58: 921-929. doi: 10.1007/s00248-0099531-y.

[3].Bhardwaj D, Ansari MW, Sahoo RK, Tuteja N 2014. Biofertilizers function as key player in sustainable agriculture by improving soil fertility, plant tolerance and crop productivity. Microb Cell Fact, 13: 66. doi: 10.1186/1475-285913-66.

[4].Bhattacharyya PN, Jha DK 2012. Plant growth-promoting rhizobacteria (PGPR): emergence in agriculture. World $J$ Microbiol Biotechnol, 28(4): 1327-1350.

[5].Bonfante P, Iulia-Andra A 2009. Plants, mycorrhizal fungi, and bacteria: a network of interactions. Annu. Rev Microbiol, 63: 363-383.

[6].Bouizgarne B. 2013. Bacteria for plant growth promotion and disease management. In: Bacteria in agrobiology, disease management, D K Maheshwari (Ed.), Springer Verlag, Berlin, Heidelberg, pp. 15-34.

[7].Bray RH, Kurtz LT 1945. Determination of total, organic and available forms of phosphorus in soils. Soil Sci., 59: 3945.

[8].Fatima Z, Zia M, Chaudhary MF 2007. Interactive effect of Rhizobium strains and P on soybean yield, nitrogen fixation and soil fertility. Pak J Bot, 39: 255-264

[9].Grossman JM, Schipanski ME, Sooksanguan T, Drinkwater LE 2011. Diversity of rhizobia nodulating soybean Glycine max (Vinton)] varies under organic and conventional management. Appl Soil Ecol, 50: 14-20.

[10]. Hussain N, Mujeeb F, Tahir M, Khan GD, Hassan NM, Bari A 2002. Effectiveness of Rhizobium under salinity stress. Asian J Plant Sci, 1: 12-14.

[11]. Jackson ML 1962. Soil Chemical Analysis. Prentice Hall of India Pvt. Ltd. New Delhi.

[12]. Khaitov B, Kurbonov A, Abdiev A 2016. Effect of chickpea in association with Rhizobium to crop productivity and soil fertility, Eurasian J Soil Sci, 5 (2): 105-112. doi: http://dx.doi.org/10.18393/ejss.2016.2.105-112

[13]. Mfilinge A, Mtei K, Ndakidemi P 2014. Effect of Rhizobium inoculation and supplementation with phosphorus and potassium on growth and total leaf chlorophyll (chl) content of bush bean Phaseolus vulgaris L. Agricultural Sciences, 5: 1413-1426. 
[14]. Nazir N, Mirza JH, Akhtar N, Bajwa R, Nasin G 2007. Some studies of thermophilic and thermotolerant fungi from Lahore, Pakistan. Mycopath, 5: 95-100.

[15]. Nehra K, Yadav SA, Sehrawat AR, Vashishat RK 2007. Characterization of heat resistant mutant strains of Rhizobium sp. [Cajanus] for growth, survival and symbiotic properties. Indian J Microbiol, 47: 329-335. doi: 10.1007/s12088-007-0060-4.

[16]. Nina K, Thomas WK, Prem SB 2014. Beneficial organisms for nutrient uptake. VFRC report 2014/1, virtual fertilizer research center. Washington, DC: Wageningen Academic Publishers, p. 63.

[17]. Patil PL, Medhane NS 1974. Seed inoculation studies in gram (Cicer arietinum) with different strains of Rhizobium sp. Plant Soil, 40: 221-223. doi: 10.1007/BF00011425.

[18]. Rad HN, Sayadi V, Rad AN 2014. Effect of Rhizobium bacteria (Rhizobium leguminosarum) and nanoiron application on yield and yield components of different pinto beans genotypes, Agricultural Communications, 2(2): $22-27$.

[19]. Ramachandran VK,East AK, Karunakaran R, Downie, JA, Poole PS 2011. Adaptation of Rhizobium leguminosarum to pea, alfalfa and sugar beet rhizosphere investigated by comparative transcriptomics. Genome Biol, 12: 106-109. doi: 10.1186/gb-2011-12-3-106.

[20]. Rashid MH, Schafer H, Gonzalez J, Wink M 2012. Genetic diversity of rhizobia nodulating lentil (Lens culinaris) in Bangladesh. Syst Appl Microbiol, 35: 98-109. doi: 10.1016/j.syapm.2011.11.008.

[21]. Sahoo RK, Ansari MW, Dangar TK, Mohanty S, Tuteja N 2013. Phenotypic and molecular

[22]. characterization of efficient nitrogen fixing Azotobacter strains of the rice fields. Protoplasma, doi:10.1007/s00709013-0547-2.

[23]. Sharma AK, Bhattacharyya PN, Rajkhowa DJ, Jha DK 2015. Impact of global climate change on beneficial plantmicrobe association. Annals of Biological Research, 5 (3): 36-37.

[24]. Sharma P, Sardana V, Kandola SS 2011. Response of groundnut (Arachis hypogaea L.) to Rhizobium inoculation. Libyan Agric Res Centre J Int, 2: 101-104.

[25]. Singh B 2003. Improving the production and utilization of cowpea as food and fodder. Field Crops Research, 84: $169-150$.

[26]. Singh JS, Pandey VC, Singh DP 2011. Efficient soil microorganisms: a new dimension for sustainable agriculture and environmental development. Agric Ecosyst Environ, 140: 339-353. doi: 10.1016/j.agee.2011.01.017.

[27]. Sinha RK, Valani D, Chauhan K, Agarwal S 2014. Embarking on a second green revolution for sustainable agriculture by vermiculture biotechnology using earthworms: reviving the dreams of Sir Charles Darwin. Int J Agric Health Saf, 1: 50-64.

[28]. Subbiah BV, Asija GL 1956. A rapid procedure for assessment of available nitrogen in soils. Curr Sci, 25: 259-260.

[29]. Tagore GS, Namdeo SL, Sharma SK, Kumar N 2013. Effect of Rhizobium and phosphate solubilizing bacterial inoculants on symbiotic traits, nodule leghemoglobin, and yield of chickpea genotypes, International Journal of Agronomy, Article ID 581627, 8 pages. http://dx.doi.org/10.1155/2013/581627.

[30]. Tilak KVBRN, Ranganayaki KK, Pal R, De AK, Saxena C, Shekhar Nautiyal, Shilpi Mittal, Tripathi AK, Johri BN 2005. Diversity of plant growth and soil health supporting bacteria. Curr Sci, 89(1): 136-150.

[31]. Trabelsi D, Mhamdi R 2013. Microbial Inoculants and Their Impact on Soil Microbial Communities: A Review. Bio Med Research International, Article ID 863240, 11 pageshttp://dx.doi.org/10.1155/2013/863240.

[32]. Ushamalini C, Rajappan K, Gangadharan K 1998. Seed borne mycoflora of cowpea (Vigna unguiculata [L.] Walp.) and their effect on seed germination under different storage conditions. Acta Phytopathologica et Entomologica Hungarica, 33: 285-290.

[33]. Waksman SA 1927. Principles of soil microbiology, William \& Wilkins Co., Batimore. 


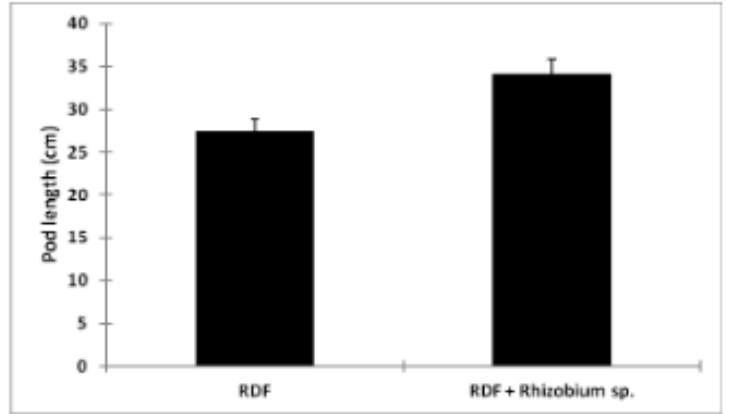

Fig 1: Pod length $(\mathrm{cm})$ cowpea in different treatments

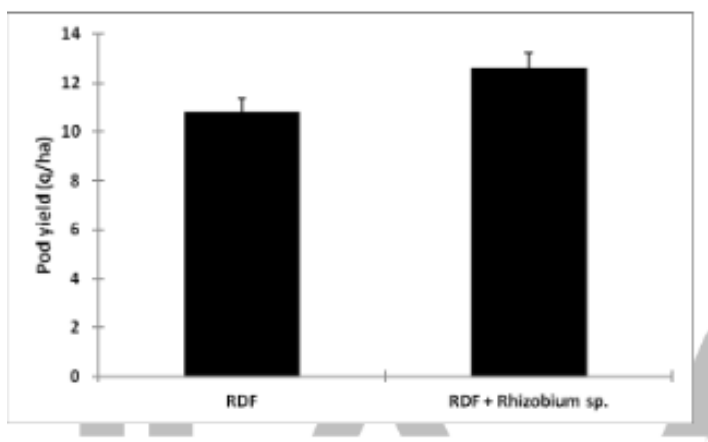

Fig 3: Pod yield ( $\left.\mathrm{q} \mathrm{ha} \mathrm{h}^{-1}\right)$ cowpea in different treatments

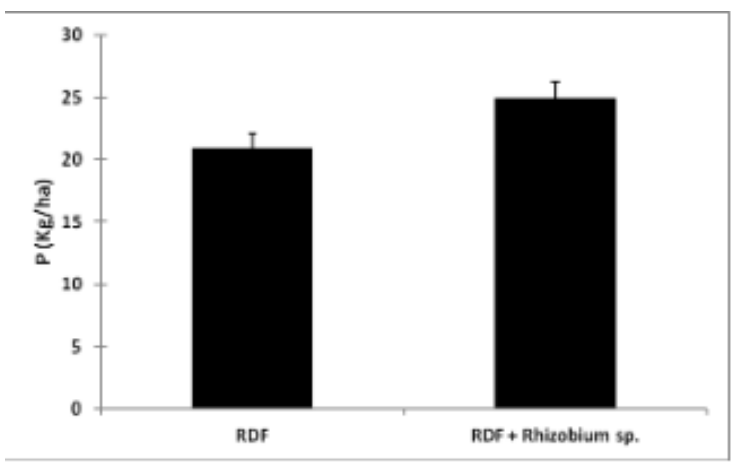

Fig 5: Phosphorus $\left(\mathrm{kg} \mathrm{ha}^{-1}\right)$ content in the post harvest soil

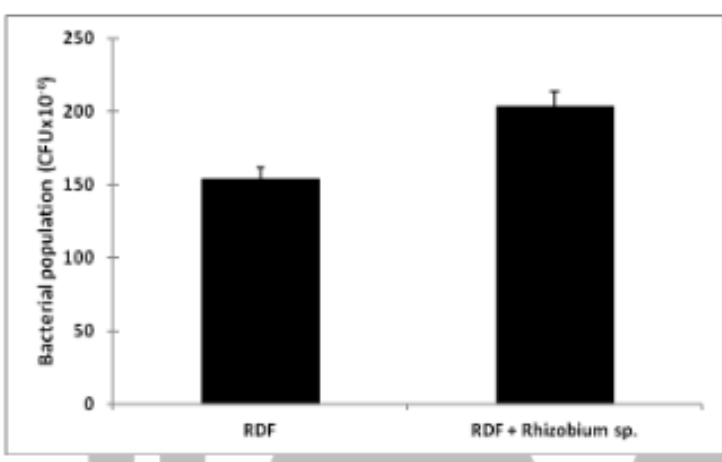

Fig 7: Bacterial population $\left(\mathrm{CFU} \times 10^{-6}\right)$ in the post harvest soil

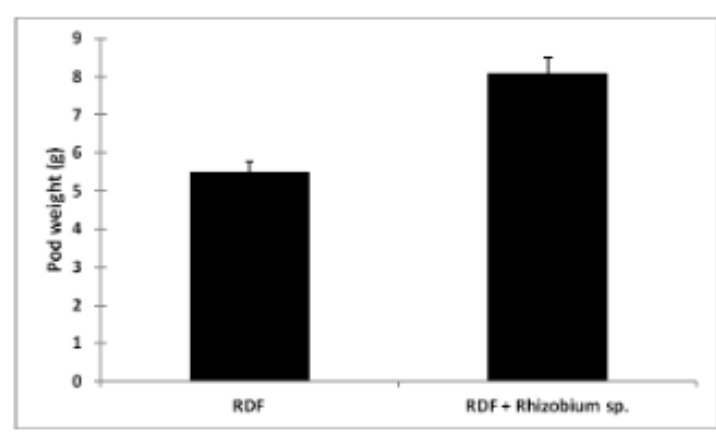

Fig 2: Pod weight (g) cowpea in different treatments

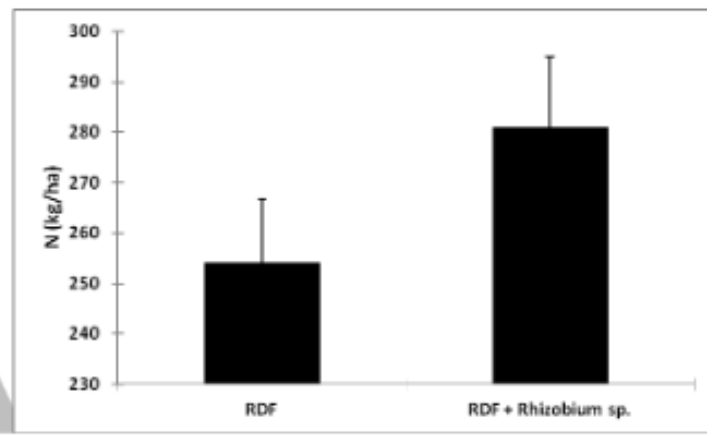

Fig 4: Nitrogen $\left(\mathrm{kg} \mathrm{ha}^{-1}\right)$ content in the post harvest soil

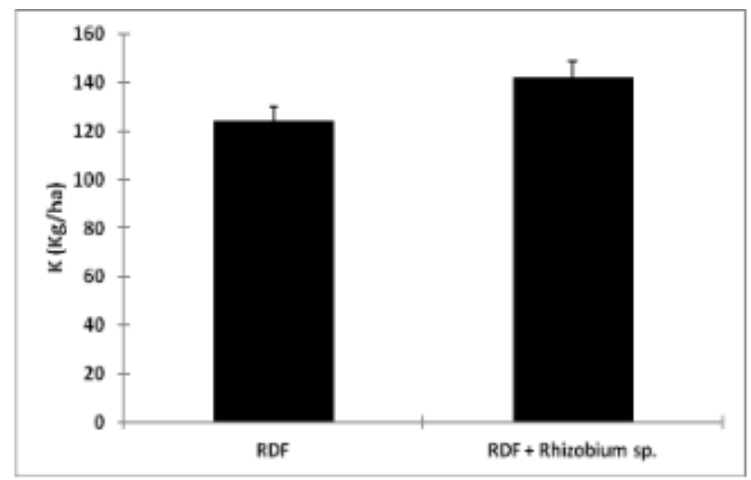

Fig 6: Potassium $\left(\mathrm{kg} \mathrm{ha}^{-1}\right)$ content in the post harvest soil

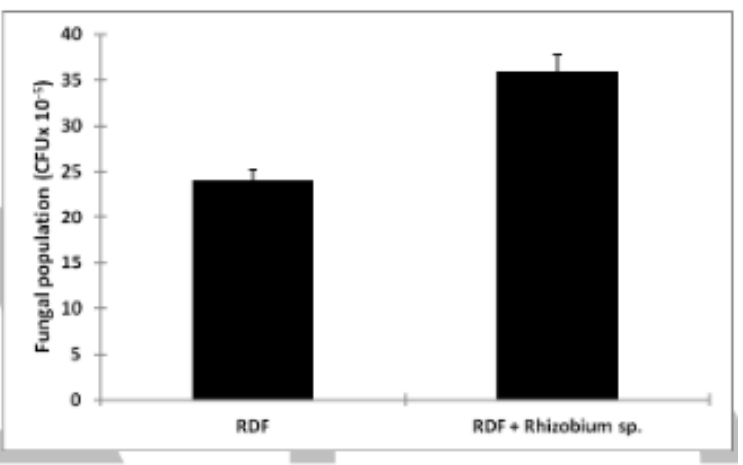

Fig 8: Fungal population (CFU $\left.\times 10^{-5}\right)$ in the post harvest soil 